International Journal of Trend in Scientific Research and Development (IJTSRD) International Open Access Journal |www.ijtsrd.com

No: 2456 - 6470 |Conference Issue - ICDEBI-2018

INTERNATIONAL CONFERENCE ON DIGITAL ECONOMY AND

ITS IMPACT ON BUSINESS AND INDUSTRY

Organised By: V. P. Institute of Management Studies \& Research, Sangli

\title{
Digital Economy and Development of E-Commerce
}

\author{
Dr. Vishakha Apte \\ Professor, Department of MBA,
}

Chhatrapati Shahu Institute of Business Education and Research, Kolhapur, Maharashtra, India

\begin{abstract}
Everywhere in the world the production and businesses processes are becoming more and more computer and Information Technology based. According to the 'techopedia' definition of Digital Economy is a common term used for all those economic processes, transactions, interactions and activities that are based on digital technology. It is not only based on the use of internet but any of the many digital tools used in today's world.
\end{abstract}

As a part of the digitalization of business processes the method of marketing and selling have seen a revolutionary change that is in the form of Ecommerce. Again quoting 'Technopedia'

Electronic commerce is the marketing, buying and selling of merchandise or services over the internet. It encompasses the entire scope of online product and service sales from start to finish. The digital tools used in ecommerce include computer platforms, applications, solutions servers and various software formats manufactured by e-commerce service providers and for increasing and facilitating online sale and purchase.

Ecommerce is as much a need of the buyers as the sellers. There are digital modes of financial transactions associated with ecommerce as online payments and refunds are to be managed.

\section{Objectives:}

The main objective is to study the development of Ecommerce during the last decade as a result of the digitalization of commercial processes. Other objective is, to study some real examples like, the experience and extent of digital platforms used by the biggest ecommerce company like Amazon.

\section{Methodology:}

The information will be collected from secondary sources like, published articles in journals, company web sites through internet and by using library resources. Necessary data will be gathered from secondary sources. This being a qualitative research paper less data will be used.

KEYWORDS:Ecommerce, digital platforms, digital economy, digital transactions.

\section{INTRODUCTION}

The term digital economy became part of everybody's life in India after Prime Ministershri. NarenderaModi launched the program of Digital India on $1^{\text {st }}$ July 2015. Digital India is an initiative of the Government of India to ensure that government services are made available to citizens electronically by improving online infrastructure and by increasing internet connectivity. Each and every Indian came in the gamut of digitalization over last decade. Some of the changes were already taking place and activities in the economy were becoming digital activities even before digital India project was launched but now it has become essential to go one step ahead and take it to the common people. Let us understand what digital economy means and what are its implications? Merely having access to digital products as users or consumers will not suffices but more appropriate will be to understand the changing economic references of the age old economic activities such as buying and/or selling in the digitalized era, digitally enabled processes and the future path. The paper attempts to 
through light on the connection between the digital economy and development of Ecommerce. For this purpose, meaning and definition of both the concepts is presented below.

\section{Digital Economy:}

According to the 'techopedia' definition of Digital Economy, it is a common term used for all those economic processes, transactions, interactions and activities that are based on digital technology. It is not only based on the use of internet but any of the many digital tools used in today's world. The continuous technological innovations are broadening the scope of digital economy. This includes the embedding of connected sensors into more and more objects (the Internet of things); new end-user devices (mobile phones, smart phones, tablets, net books, laptops, 3D printers); new digital models (cloud computing, digital platforms, digital services); growing intensity of data usage through spread of big data, data analytics and algorithmic decision-making; and new automation and robotics technologies (OECD 2015).

\section{Defining Ecommerce:}

OECD definition of an e-commerce transaction: "...the sale or purchase of goods or services,

Conducted over computer networks by methods specifically designed for the purpose of receiving or placing of orders". Whereas the Payment and delivery do not have to be conducted online.

Orders made by telephone calls, fax or manually typed e-mail excluded from e-commerce's definition here.

\section{Business-to-business (B2B)}

Online sales between enterprises, including linked to outsourcing and off shoring.

Online presence needed for SMEs to participate in value chains.

\section{Business-to-consumer (B2C)}

Involves sales by "pure play" e-commerce enterprises and traditional bricks-and-mortar firms adding online sales channels.

Many ways to reach consumers: social networks, crowd sourcing, e-commerce websites, mobile applications.

Consumer-to-consumer (C2C): e.g. eBay
Government-to-business (G2B): e.g. e-procurement, e-tendering etc.

WTO definition of e-commerce for its studies and papers is, "the production, distribution, marketing, sale or delivery of goods and services by electronic means".

Again, quoting 'Technopedia' 'Electronic commerce is the marketing, buying and selling of merchandise or services over the internet'. It encompasses the entire scope of online product and service sales from start to finish. The digital tools used in ecommerce include computer platforms, applications, solutions servers and various software formats manufactured by Ecommerce service providers and for increasing and facilitating online sale and purchase.

There is much more than simple internet involve in digital Ecommerce. According to eMarketer Ecommerce companies are highly involved in digital advertising along with digital marketing.

\section{Development of Ecommerce during the last decade and use of Digital Platforms:}

The UNIDO's working paper published in 2017 on 'National Development of ecommerce in India'; there is an exponential growth of Ecommerce in India during the last decade. Further the report states that, The E-commerce industry was worth Rs. 351 (5.4 billion US \$) billion in 2011 grew at a CAGR of $37 \%$ to touch Rs. 1257 billion in 2015, and is estimated to become a Rs. 2,110 billion ( 31 billion US \$) industry by 2016 . The same reports projects the value of ecommerce in India till 2020, 101.90 \$billions. The ecommerce growth projections show that,

Table 1:E-commerce size (\$ billions) in India:

\begin{tabular}{|c|c|c|c|c|}
\hline 2013 & 2014 & 2015 & 2018 & 2020 \\
\hline 2.9 & 13.6 & 16 & 40.3 & 101.90 \\
\hline
\end{tabular}

Source: UNIDO's working paper (2017) on 'National Development of ecommerce in India

Table 2:The size of Ecommerce sector in India expressed in Rupees:

\begin{tabular}{|c|c|c|}
\hline Year & Rupees Billion & Percentage growth \\
\hline 2011 & 351 & $34 \%$ \\
\hline 2012 & 473 & $35 \%$ \\
\hline 2013 & 533 & $13 \%$ \\
\hline 2014 & 815 & $53 \%$ \\
\hline 2015 & 1257 & $54 \%$ \\
\hline 2016 & 2110 & $68 \%$ \\
\hline
\end{tabular}

Source: UNIDO's working paper (2017) on 'National Development of ecommerce in India 
In terms of diversity of Ecommerce number of companies have been developed and entered India during last five years. In the range of products and services also there is a continuous addition to the economy. Snapdeal.com, Amazon.com, Flipkart.com (now with Wal-Mart). BigBasket.com, FirstCry.com, Zovi.com, Uber.com, olacabs.com, Cloudacar.com,quickr.com, olx.in, cloudBuy.com, tolexo.com, industrybuying.com, power2sme.com, Amazonbusiness.com, Retailers Shoppers Stop Ltd., Infiniti Retail Limited and the range is increasing to cover multiple sectors such as travel, education, fashion, healthcare, real estate, furniture, grocery and food products, entertainment and many more. The prominent names include, Makemytrip.com, yatra.com, cleartrip.com, goibibo.com Online Real Estate Magicbricks.com, 99acres.com, commonfloor.com, Housing.com Online Fashion Jabong.com, Myntra.com, Zovi.com, yepme.com, limeroad.com, Fabfurnish.com, Pepperfry.com, Online Furniture urbanladder.com Online Education Purple Squirrel Eduventures, Plancess.com Online Food and grocery Zomato.com, Foodpanda.in, TinyOwl.com, BigBasket.com, Grofers.com etc.

\section{Worldwide Development of Ecommerce:}

UNCTAD conference 2017 paper on, 'ECommerce: Global trends and developments' by

Sven CallebautLead Consultant, eTrade Readiness AssessmentsDivision on Technology and Logistics, has presented the data collected from US Census Bureau; Japan Ministry of Economy, Trade and Industry; China Bureau of Statistics; KOSTAT (Republic of Korea); EUROSTAT (for Germany); UK Office of National Statistics; INSEE (France); Statistics Canada; Australian Bureau of Statistics and INE (Spain), which shows the world wide trends in major ecommerce markets. In USA Ecommerce is $39 \%$ of GDP, in Japan $60 \%$, China $18 \%$, Korean Republic 84\%, Germany 27\%, UK 30\%, France 23\%, Canada 26\%, Spain 20\% and Australia 16\%. Ecommerce as a percentage of GDP has increased in Developed countries and also in the Developing countries. The eMarketer had predicted in July 2014 that the B2C Ecommerce Sales world Wide over the period from 2013 to 2018 would increase from $\$ 1.233$ Trillion to $\$ 2.356$. While during this period the share of Asia-Pacific region would be highest i.e. 37.4\% while that of North America would be 30.6\% and Western Europe would be $22.7 \%$. The Asia-Pacific region is expected to become leading region in ecommerce sales. The increase of ecommerce sales is tied to a growing base of digital buyers or online buyers.

\section{The digital platforms used by Ecommerce Companies:}

The consumers all over the world have become digitally active and expect the digitalization of most of the needs of their life. The digital solutions for the needs of the common people have been continuously increasing. Changing customer behavior is another significant factor which every service or product manufacturer as well as provider will take in to consideration before taking any other business decision. Customers spend the majority of their time on digital (e.g. social, messaging) platforms. Hence, Ecommerce companies, financial institutions, educational institutions, healthcare providers must position themselves where their customers are, and create a corresponding digital platform strategy relevant for their market position, customer service proposition and strategic objectives.

From the digital platform provider's perspective, partnerships with Ecommerce companies help create an ecosystem where customers need not leave their home or work place if they need anything and thus become a tension free part of their lives. The creation of online payment gateways and the online banking services as well as other online payment service providers like Paytm have become the important part of the Ecommerce ecosystem. As the economy started to grow more demanding for digital transactions more platforms came in to market. The two sided simple buyer seller platforms are now replaced by multisided platforms that bring together consumers, service providers and stakeholders to facilitate value exchange as part of a larger ecosystem. All the agents of the Ecommerce ecosystem actively contribute to its development. The digitalized advertising by Ecommerce companies is another area where digital platforms are widely used but since consumers do not directly come into contact with these digital advertising platforms as they remain in the background there is less awareness about it.

\section{Ecommerce at Amazon:}

The digital platform used by the biggest Ecommerce Company Amazon is its own creation. It does not make use of digital solutions created by others for its main online retail platform. It is done through AWS that is Amazon Web services. 10 years ago, Amazon Web Services, the cloud Infrastructure as a Service arm 
of Amazon.com, was launched with little fanfare as a side business for Amazon.com. Today, it's a highly successful company in its own right, riding a remarkable $\$ 10$ billion run rate. The close competitors of AWS are Microsoft, IBM and Google. AWS is the most successful cloud infrastructure company. It's ahead of the other three. In the year 2000 Amazon started its own web services through its own internal developers. AWS was developed by Amazon for fulfilling its own internal requirements of an operating system. The company does not use digital platforms developed by outside agencies. While their competitors in the field of ecommerce use the services of Google, Microsoft and IBM. Developing the internal operating system for the internet was the major step in the success of Amazon in the ecommerce business. Parallel to ecommerce it is a service company too.

\section{The Latest Trends in Ecommerce:}

A major trend in ecommerce this year is international retailers investing across Asia-Pacific to gain access to markets. With special reference to India, 'Walmart's May 2018 purchase of Flipkart. Flipkart is India's major home grown digital retailer. India, with its population of 1.3 billion people, represents the biggest opportunity in Asia-Pacific for retailers. This year, ecommerce will account for just $2.9 \%$ of overall retail sales, which translates to $\$ 32.70$ billion. Fertile ground for growth fuelled the bidding war between Amazon and Walmart for Flipkart.

Prior to the Flipkart bidding war, Amazon had already invested in or acquired at least six ecommerce platforms in India. Those investments led to Amazon capturing $30 \%$ of India's ecommerce market, per a May 2018 Citi Research report. Acquiring Flipkart, which holds $30 \%$ of the market according to Citi Research, would have clinched dominance in India for Amazon.

Walmart's strong desire to enter India, however, led it to outbid Amazon, paying roughly $\$ 16$ billion to secure Flipkart. (Source: eMarketer). Simultaneously there is digital transformation taking place in the financial services sector. On the other hand in 2017 KPMG International and Microsoft today announced two important strategic initiatives that will expand the scope of their global alliance: providing clients with a portfolio of digital solutions and enabling KPMG's smart audit platform, KPMG Clara - both built on KPMG business experience and the Microsoft intelligent cloud. There are several examples of such strategies in the global business where digitalization is the key to expansion.

\section{Conclusion:}

Process of digitalization of the economy may be at different level in different countries. Within an economy also all sectors may have a different pace of digitalization. Consumer retailing has become most popular due to digital transactions. But the biggest Ecommerce Company relies only on its own digital platform providers rather than using outside ones. Experts in this field have stated that the growth of B2B transactions in digital form is higher than B2C transaction. Digitalization is expected to spread to many more sectors and activities in the coming future. The growth prospects are unlimited though challenges exist.

\section{REFERENCES:}

1. EceIdil KASAP (2016) Conference paper Digital Economy: Opportunities and Challenges for SME Development30t h CACCI Conference November 24, 2016 Director of Online Solutions, World SMEForum@worldsmeforum

2. Sven Callebaut (2017) Session presentation Ecommerce Global trends and Developments UNCTAD

3. Dr. Lames Manyika ( 2015 ) Digital Economy: Trends Opportunities and challenges: McKinsey Report

4. AlirezaAlipourMarzangou, MortezaGhorbani, SogandRanbarVandi, SinaKhodami, SaeedSaadati, MeghdadAminianInternational J. Soc. Sci. \& Education

5. June-2014 Vol.4 (Special Issue), ISSN: 2223$4934 \mathrm{E}$ and 2227-393X Print.

6. KPMGhttps://home.kpmg.com/xx/en/home/insights/2018 /02/rise-of-digital-platforms-fs.html

7. https://techcrunch.com/2016/07/02/andy-jassysbrief-history-of-the-genesis-of-aws/ 